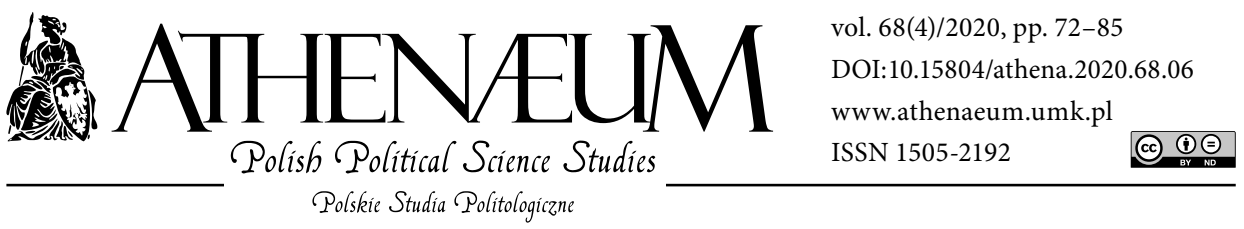

\title{
IDEAS AS AN EXPLANATORY FACTOR IN POLITICAL ANALYSIS*
}

\author{
IDEE JAKO CZYNNIK WYJAŚNIAJĄCY W ANALIZIE \\ POLITYCZNEJ
}

Piotr Burgoński**

The purpose of the article is to demonstrate that ideas can be treated as a factor explaining political stability and change. Based on the completed analytical tasks, it has been found that ideas have their own dynamics and therefore they deliver unique effects, influencing change or stability of policies. The article demonstrates that the impact ideas have on the political process depends on the understanding of human behaviour in the field of politics. The article reviews the ideational dimension with reference to behaviours covered by the rational choice theory, by historical, sociological and discoursive institutionalism and constructivism. As a result of the analytic tasks, certain differences have been revealed between the above mentioned approaches in terms of understanding the impact of ideas. What the approaches have in
\end{abstract}

\begin{abstract}
Celem artykułu jest wykazanie, że idee mogą być traktowane jako czynnik wyjaśniający polityczną stabilność i zmianę. Przeprowadzone analizy pokazały, że idee odznaczają się własną dynamiką, w wyniku której powodują specyficzny efekt wpływający na zmianę polityki lub jej stabilność. Artykuł pokazuje, że wpływ idei na proces polityczny jest uwarunkowany sposobem rozumienia zachowań człowieka w sferze polityki. W artykule poddano analizie wymiar ideacyjny w odniesieniu do zachowań, o jakich jest mowa $\mathrm{w}$ teorii racjonalnego wyboru, historycznym, socjologicznym i dyskursywnym instytucjonalizmie oraz konstruktywizmie. W rezultacie analiz ujawniono różnice pomiędzy tymi podejściami w zakresie rozumienia wpływu idei. Tym, co je łączy, jest ścisły związek idei z aktorami politycz-
\end{abstract}

* This article is among the deliverables of the research programme that has received funding under the MINIATURA 3 contest organized by the National Science Centre, Poland, reg. no. 2019/03/X/HS5/02180.

** Cardinal Stefan Wyszyński University in Warsaw, Institute of Political Science and Public Administration. 
common is a close link between ideas and political actors. The article covers theoretical issues without considering methodology aspects. It is based on the outcomes of study projects carried out by authors recognized in the so-called school of ideas, formed in political science following the "ideational shift" during the $1990^{\text {s }}$ and reflecting until the present day on the ideational dimension of politics.

Keywords: ideas; political analysis; rational choice theory; institutionalism; constructivism nymi. Artykuł dotyczy kwestii teoretycznych, nie uwzględnia problematyki metodologicznej. Opiera się na rezultatach badań przeprowadzonych przez autorów zaliczanych do tzw. szkoły idei, która powstała $\mathrm{w}$ naukach politycznych po „ideacyjnym zwrocie” w latach 90. ubiegłego wieku i również dzisiaj podejmuje refleksję nad wymiarem ideacyjnym polityki.

Słowa kluczowe: idee; analiza polityczna; teoria racjonalnego wyboru; instytucjonalizm; konstruktywizm

An "ideational shift" in political studies occurred during the 1990s, involving an abandonment of the rational choice theory which used to prevail by that time, to resort to a type of analysis in which ideas play an important role. The key rational choice concepts would refer to the state of stability, while they considered change to a much lesser degree. In the meantime, research was focused on the analysis of the political change taking place at that point. By reorientation of research from stability analysis to change analysis, researchers turned to ideas as a factor capable of explaining the reasons behind the change.

Among the significant empirical studies where ideas are treated as an explanatory factor, we can mention, for example, the work of Sheri Berman (1998; about the impact of ideas on the capitulation of the Social Democratic Party of Germany in light of the Nazi system and the ability of the Social Democratic Workers' Party of Sweden to avoid the threat of fascism), Mark Blyth (2002; about the role of economic ideas in the institutional transformation of the $20^{\text {th }}$ century), Geoffrey Garret and Barry Weingast (1993; about the impact of ideas on the evolution of the European Communities towards the establishment of a single unified market), Judith Goldstein (1993; about the impact of ideas on the trading policies of the United States), Peter Hall (1992; about the effect of the monetarism idea on British policies), or Kathleen McNamara (1998; about the consensus of elites around the common ideas that has led to the establishment of the European Monetary Union).

The purpose of this paper is to convince the reader that ideas can be treated as a factor that explains both political stability and change. For this purpose, it will be necessary to demonstrate that ideas are characterized by their specific 
and unique dynamics, leading to the emergence of a specific effect. Moreover, the article will present the method according to which ideas can be treated as an explanatory factor. The analytic tasks included in the article are intended to prove that the method of presenting ideas as a factor affecting the political process depends on the specific understanding of human activity in the field of politics. Hence, the issue of ideational explanation is reviewed in the article on the grounds of the assumptions of several theories, offering different representations of the behaviours of political actors, namely: the rational choice theory; the three variants of the institutional theory; and constructivism.

Section 1 in the article is dedicated to an explanation of how to understand ideas. The following sections cover the following sequence of issues: causality; form of impact; and the effect generated by ideas within the process of political change/stability. The article covers theoretical issues without considering methodology aspects. It has been written primarily on the basis of the findings of researchers representing the so-called school of ideas (Peter Hall, Sheri Berman, Mark Blyth, Colin Hay, Vivien Schmidt, Kathleen McNamara, and others), which was formed in political studies following the "ideational shift".

\section{WHAT IDEAS ARE}

Ontological individualism is the approach used in the rational choice theory, as well as the rational choice institutionalism, meaning that individuals are treated as irreducible components of social and political life. All that exists in the social reality is due to individuals. Pursuant to these assumptions, individual mental processes are the sources of ideas, while the ideas as such are defined as beliefs of which individuals are carriers. Moreover, it is presumed in the rational choice theory that individuals strive to maximize utilitarian value in their doings. Therefore, ideas are presented as products intentionally developed by individuals with the objective of maximizing their own benefits. Individuals use ideas instrumentally as long as they find them useful in achieving their goals. Whereas individuals are primary in theoretical terms, ideas as instrumental products are incapable of altering the preferences of individuals (Blyth, 2006, pp. 306-308).

The historical institutionalism contests the belief represented by the rationalist theory about the decisive role of the actors, and instead it focuses more on the importance of structures, or rather institutions that affect the actors' behaviours. Ideas are defined here as cognitive entities which are institutionalized with the 
time passing, and in that form they set the direction for the actors. Historical institutionalism generally disregards the origin of ideas or their creation process, treating institutionalized ideas as the reality actors find as it is (Tønder, 2010, p. 59).

Sociological institutionalism presents ideas as a collective understanding of social facts, composed of claims regarding the characterization of the world, causal relations and normative legitimization of specific actions. It places ideas in a cultural (social) context, emphasizing that they are determined by culture (society) (Saurugger, 2013, pp. 892-893). Yet neither historical nor sociological institutionalism deals with ideas as constructs functioning on the basis of individual rules.

The origin and creation of ideas is the area of interest of discoursive institutionalism. It shows that the process of creating ideas, having individual thought at its foundation, takes up the form of collective action. This is because ideas are generated, expressed, deliberated on, discussed and legitimized in an interactive process of exchange, which takes place in a specific institutional context. This process is called discourse and ideas are the substance of it (Schmidt, 2010, p. 15).

It is assumed on the grounds of constructivism that the reality in which the actors move is dualistic, ideational and materialistic at the same time. It is composed of social constructs, such as ideas, hidden in people's consciousness and shared by them together, as well as material (empirical) entities. The process of generating ideas in constructivism is sometimes understood as creating a representation of the material reality, consisting of interpreting that reality, or in other words giving it a specific meaning (Béland, 2016, p. 430). Constructivism attributes an inter-subjective character to ideas, believing that they belong to the socially construed world. Specifically, ideas originate from and are formed (construed) through continuous human interactions (i.e., the social world) (Wiener, 2006, pp. 43-44).

\section{CAUSALITY OF IDEAS}

The impact of ideas on the political process can be conceptualized in two different ways. The first of these, usually occurring on the grounds of rationalist theories, is called causal logic, while the other one, present in constructivist and similar theories (specifically in sociological and discoursive institutionalism), is called constitutive logic. 
When explaining the impact of ideas, the rational choice institutionalism refers to the causal logic, where the central assumption is the independent existence and temporal asymmetry between the cause and effect. Hence, this type of logic is based on a narrow understanding of causality, referring to David Hume's concept: if $\mathrm{X}$ is supposed to be the cause of $\mathrm{Y}$, then $\mathrm{X}$ must exist independently of $\mathrm{Y}, \mathrm{X}$ must precede $\mathrm{Y}$ in time, and $\mathrm{Y}$ must follow every occurrence of $\mathrm{X}$. This logic is therefore mechanistic, as it presumes a fixed relationship: cause $\mathrm{X}$ must produce effect Y. According to this type of logic, ideas are treated as separate variables causing a mechanistic and autonomous effect in terms of policy results (Gofas \& Hay, 2010, pp. 39-40).

Similarly, historical institutionalism accounts for the causality of ideas, treating them as independent variables. The assumption here is that causality exists when there is a link between ideas as independent variables and dependent variables. This link can be demonstrated when a particular idea, existing in time $\mathrm{T}$, which cannot be reduced to another variable, generates an effect in time $\mathrm{T}+1$. The above implies that in explaining the way ideas affect a change in policy, historical institutionalism uses the causal logic scheme (Tønder, 2010, p. 60).

Constructivism and the theoretical approaches akin to it (i.e., sociological and discoursive institutionalism) refer to constitutive logic in their analysis of the role of ideas in the political process. Within the framework of non-constructivist theories, ideas and norms people "believe" are viewed as purely consolidated rationalizations of certain sets of relatively rational answers to certain "real" - as opposed to societally constructed - sets of incentives and limitations. In other words, non-constructivist theories claim that people accept ideas through a relatively reasonable and objective process. Therefore, ideas do not constitute anything. When it is claimed in the context of historical institutionalism that institutionalized ideas restrict the actors or enable them to act, the only meaning is the behavioural effect (without any change of the actors' interests or identities). From the constructivist point of view, as people adopt ideas, they start living in a world defined by a set of meanings incorporated in the ideas. A change of ideas makes a difference between separate worlds. Constituting is a logically different relationship than cause-and-effect conditioning. If ideas as parts of a structure constitute an actor, it means that the actor's specific qualities do not exist without a structure. Specific ideas make actors behave in a particular way, while different ideas make them act differently (Parsons, 2010, p. 87). 


\section{HOW IDEAS MAKE THEIR IMPACT}

The rational choice theory turned to ideas because it was not able to explain the stability of institutions. Institutions represented by that theory are selected structures, treated instrumentally and formed by people with the intention to accomplish stability and to maximize the advantage of individuals. However, a question arises about why institutions persist even though they are irrational from the perspective of individuals' interests, as their maintenance and control require dedicating specific resources, and they restrict the options for an egoistic strive towards maximizing one's individual advantages. If the rational choice theory allows for the presence of ideas as independent variables, it only does so because materialistic factors are not sufficient to explain political processes. Hence, ideas are treated as auxiliary variables. The theory does so while retaining its own presumptions to the effect that ideas do not change the essence of the intentions of individuals because those intentions are permanent and external towards ideas (maximizing advantages), while ideas are only instrumental constructs (Blyth, 2006, pp. 42-47).

Historical instrumentalism is not very successful in dealing with the question why certain entities start believing that institutions, which have been in existence for a long time and within which other entities used to function, should be changed. In order to explain change without having to resort to external factors, historical institutionalism turned to ideas. It is claimed on the grounds of historical institutionalism that institutions and ideas are original and superior towards individuals in ontological (and not historical) terms. It implies that the institutional and ideational context affects individuals by defining the essence of their preferences and aspirations. With the change of ideas, preferences of individuals tend to change as well. Ideas play the role of independent variables, explaining a change in politics, so that they induce change in the preferences of individuals, which in turn stimulates individuals to take action to change the institutions (Blyth, 2006, pp. 308-310).

Sociological institutionalism assumes that ideas direct the actors' activity via institutions. From the perspective of this theory, institutions are defined broadly, as formal and informal norms, cultural conventions and cognitive frameworks. Sociological institutionalism claims that human action is directed by the logic of relevance, i.e., the principles of appropriate/model behaviour, which are fixed in the form of institutions. Actors follow the rules because they perceive them as 
natural, appropriate, expected and legitimate, and not because they would best correspond with their individual interests (Saurugger, 2017, p. 5).

Sociological institutionalism did not have to turn to ideas because ideas are the foundation of that approach (Schmidt, 2010, p. 13). On this foundation, ideas are presented as a factor that influences the emergence of a new institution or a change of an existing one, as well as the actors' behaviours. Sociological institutionalism emphasizes that the process of emergence/change of institutions is socially conditioned. It starts at the point when the actors are confronted with an idea, exported from the outside and expressing a different understanding of what is permitted and what is forbidden. The new normative understanding is promoted by specific political entrepreneurs who try to encourage various actors to accept it as their own. If the actors adopt the new ideas, it happens through cognitive mechanisms: socialization and social learning process. Success of the entrepreneurs' actions depends primarily on their ability to use rhetorics strategically in order to win new supporters (Saurugger, 2013, p. 894). If the entrepreneurs are capable of acting in this way, the normative idea they propose will develop further towards becoming a fully matured norm or institution. Yet a successful completion of the process depends on whether the structural environment is ready to accept the new idea and whether that idea is consistent with the remaining normative structure, as well as on the entrepreneurs' positions and importance.

Discoursive institutionalism points out a discoursive process in which the actors generate, deliberate on, legitimize and communicate ideas in a specific institutional context, which ultimately leads to a change in institutions. On the grounds of this approach, ideas are the substance of the discourse, and the latter is represented as an exchange of ideas. Ideas are positioned not only within a cultural, but also a meaning context, which constitutes institutions of a different type than those characteristic of the theories discussed above. In this variant of institutionalism, institutions are not perceived as structures which are external towards the actors, composed of rules to be followed, mainly serving the purpose of a limitation for the actors (rationalist incentives, historical paths, cultural frameworks). Instead, institutions are presented as constructions internal to the thinking and speaking actors, which at the same time restrict the actors and stimulate their action (particularly through enabling them to construct meanings). From the point of view of discoursive institutionalism, the actors are capable of thinking and talking about institutions in a critical way, they are aware of their own and others' ways of thinking, they can persuade themselves and 
others to change their thinking about institutions, to build discourse coalitions in favor of reforms. The actors are also rational in their way of thinking: they strive to accomplish their goals in accordance with their beliefs about facts, yet as they are capable of critically reflecting on their own thinking, they are also capable to change it and, consequently, to change the way they act (Schmidt, 2010, pp. 15-18).

Constructivism rejects the rationalist presumption that material factors are the primary independent variable which explains the process of policy generation and results. The assumption here is that the understanding of material facts is defined by ideational factors. From the constructivist perspective, ideas are the causative factor, meaning that they constitute the world the actors live in, including their preferences, and in this way they influence the actors' behaviours. Yet a question arises here about why specific ideas become privileged above others, and why they are chosen to constitute the actors' preferences. In their answers to that question, some constructivist trends refer to the logic of relevance, according to which the actors adapt their actions to the normative expectations of the system (Cianciara, 2017, pp. 56-59). Yet this approach seems to be insufficient, as it disregards the power relations and strategic activities of political actors. The theory which attempts at filling these gaps is called actor-centred constructivism. Its assumption is that the actors' ideas and beliefs are constructed, yet it emphasizes the need to consider the way actors use ideas. The focus here is on the "carriers" of ideas and norms, and on how the power relations determine the outcomes of public policies. From the point of view of this theory, ideas are not only the environment in which the actors are immersed, but also tools used by the actors (Saurugger, 2013, pp. 896-898).

\section{THE EFFECTS OF IDEAS}

When we speak of ideas as independent variables, it would be reasonable to demonstrate the effect by way of which they contribute to maintained political stability or caused political change. Firstly, ideas define the political actors' perceptions of the reality. This is mainly done by cognitive (descriptive) ideas through the claims inherent in them about the states of the world, as well as the assumptions regarding causal relations, derived from complex mental processes and not constituting a straightforward description of facts. Ideas can also play the role of cognitive filters, processing human thinking and experience by 
interpreting environmental cues in a particular way. As they determine human perceptions, they are also capable of influencing the way people act (Béland \& Cox, 2011, pp. 3-4; Béland \& Cox, 2016, p. 430; Hay, 2006, p. 64). There are also certain ideas defined as beliefs shared by a community - these are called normative ideas (norms), guiding the actors' thoughts and behaviours within a specific area of political life. Ideational elements also include culture, which also provides general behavioural guidelines and rules which governs social, political and economic life (Berman, 2013, pp. 223-225).

The other impact mechanism is the functioning of ideas as roadmaps. It can be encountered when individuals lack information, which is typical of uncertain periods of time. Then, in order to resolve the problem, the actors will use ideas, as they presume specific causal relations and suggest certain strategies for achieving the goals (Gofas \& Hay, 2010, pp. 23-26).

Another effect is that ideas provide frameworks for defining the actors' interests. Ideas as interest-defining frameworks let the actors understand what is important or valuable. This role is particularly important in case of uncertainty (e.g., at a time of crisis). At such time, it is not possible to determine the actors' interests or the results of their actions on the basis of structural positioning. Hence, the actors' interests have to be defined on the basis of the ideas they share, relating to the causes of the state of uncertainty they found themselves in. In this way, ideas reduce the uncertainty and indicate the actual interests of the actors, showing which institutions best serve these interests (Blyth, 2001, pp. 3-4).

Ideas can also function as focal points to facilitate collaboration between the political actors. If the adoption of certain solutions proposed in negotiation would lead to uncertainty and instability, the use of an appropriate idea, to which all the negotiating parties agree, will streamline the cooperation and increase its stability (Gofas \& Hay, 2010, pp. 26-27).

Ideas can filter the choices the decision-making actors are confronted with. They use ideas, more or less intentionally, to help them determine the way to resolve a problem through selection among multiple potentially optimum results. John Campbell distinguishes ideas called normative frameworks, composed of presumptions perceived as obvious in terms of values, attitudes, identities and other collectively shared expectations. When the actors make their choices among the available alternatives, they use the normative frameworks as points of reference, showing them what is acceptable, legitimate, appropriate, meaningful, particularly where there is no evidence to support a particular option working best in practice (Campbell, 2002, pp. 23-26). 
In the process of creating public policies, ideas can play the role of problem definition and problem resolution. As they play the role of a problem definition, an idea will frame the specific problem by expressing a particular understanding of the complex reality. The way a problem is framed has certain significant implications as to the type of solutions that will seem to be desirable. Ideas which are problem solutions within a specific policy identify the measures to be undertaken in order to solve the problem and accomplish the goals of the specific policy (Mehta, 2011, p. 27).

When the actors want to change the existing institutional system, formed by ideas which used to be significant in the past, they use new ideas as weapons in their struggle for institutional change (Blyth, 2001, pp. 3-4). Ideas make political actors gain productive force and be capable to come to power (Parsons, 2016, pp. 451-459). Ideas are also sometimes used strategically, as the so-called coalition magnets. Coalitions come into existence thanks to a shared definition of a problem, a shared solution to a problem, a shared perception of interests, or shared extensive political and ideological goals (Béland \& Cox, 2016, pp. 429, 432).

Table 1. Ideas as a Factor Explaining Political Change in the Perspective of Various Theory Assumptions

\begin{tabular}{|l|l|l|l|l|l|}
\hline & $\begin{array}{l}\text { Rational choice } \\
\text { theory }\end{array}$ & $\begin{array}{l}\text { Historical } \\
\text { institutionalism }\end{array}$ & $\begin{array}{l}\text { Sociological } \\
\text { institutionalism }\end{array}$ & $\begin{array}{l}\text { Discoursive } \\
\text { institutionalism }\end{array}$ & Constructivism \\
\hline $\begin{array}{l}\text { Definition } \\
\text { of ideas } \\
\text { indiefs of }\end{array}$ & $\begin{array}{l}\text { cognitive enti- } \\
\text { ies which get } \\
\text { institutionalized } \\
\text { with time }\end{array}$ & $\begin{array}{l}\text { collective, cultu- } \\
\text { rally determined } \\
\text { understanding } \\
\text { of social facts }\end{array}$ & $\begin{array}{l}\text { cognitive } \\
\text { constructs } \\
\text { generated and } \\
\text { formed within } \\
\text { the discourse } \\
\text { framework }\end{array}$ & $\begin{array}{l}\text { shared social } \\
\text { constructs }\end{array}$ & preferential \\
\hline $\begin{array}{l}\text { The status } \\
\text { of ideas } \\
\text { among the } \\
\text { explanato- } \\
\text { ry factors }\end{array}$ & $\begin{array}{l}\begin{array}{l}\text { auxiliary varia- } \\
\text { mathematical } \\
\text { explanations fail }\end{array} \\
\text { variable }\end{array}$ & $\begin{array}{l}\text { preferential } \\
\text { variable, provi- } \\
\text { ded that it can } \\
\text { be defined in } \\
\text { a consistent way, } \\
\text { independent of } \\
\text { the institutions }\end{array}$ & $\begin{array}{l}\text { preferential } \\
\text { variable }\end{array}$ & $\begin{array}{l}\text { prefential } \\
\text { variable }\end{array}$ \\
\hline
\end{tabular}




\begin{tabular}{|c|c|c|c|c|c|}
\hline & $\begin{array}{l}\text { Rational choice } \\
\text { theory }\end{array}$ & $\begin{array}{l}\text { Historical } \\
\text { institutionalism }\end{array}$ & $\begin{array}{l}\text { Sociological } \\
\text { institutionalism }\end{array}$ & $\begin{array}{l}\text { Discoursive } \\
\text { institutionalism }\end{array}$ & Constructivism \\
\hline $\begin{array}{l}\text { Type of } \\
\text { causality } \\
\text { of ideas }\end{array}$ & causal logic & causal logic & $\begin{array}{l}\text { constitutive } \\
\text { logic }\end{array}$ & $\begin{array}{l}\text { constitutive } \\
\text { logic }\end{array}$ & $\begin{array}{l}\text { constitutive } \\
\text { logic }\end{array}$ \\
\hline $\begin{array}{l}\text { The origin } \\
\text { of new } \\
\text { ideas }\end{array}$ & $\begin{array}{l}\text { generated and/ } \\
\text { or promoted } \\
\text { by individuals } \\
\text { inside or outside } \\
\text { a subsystem }\end{array}$ & $\begin{array}{l}\text { generated and } \\
\text { promoted by ac- } \\
\text { tors affected by } \\
\text { institutions, insi- } \\
\text { de a subsystem }\end{array}$ & $\begin{array}{l}\text { generated and/ } \\
\text { or promoted } \\
\text { by rhetorically } \\
\text { skilled political } \\
\text { entrepreneurs } \\
\text { coming from } \\
\text { the outside of } \\
\text { a subsystem }\end{array}$ & $\begin{array}{l}\text { generated and } \\
\text { formed by cri- } \\
\text { tically thinking, } \\
\text { discoursively } \\
\text { skilled actors } \\
\text { inside a subsys- } \\
\text { tem or between } \\
\text { subsystems }\end{array}$ & $\begin{array}{l}\text { generated } \\
\text { and formed } \\
\text { through actors' } \\
\text { interaction } \\
\text { inside a subsys- } \\
\text { tem or between } \\
\text { subsystems }\end{array}$ \\
\hline $\begin{array}{l}\text { How ideas } \\
\text { make their } \\
\text { impact }\end{array}$ & $\begin{array}{l}\text { - ideas produce } \\
\text { a behavioural } \\
\text { effect on indi- } \\
\text { viduals without } \\
\text { changing their } \\
\text { preferences, } \\
\text { - individuals } \\
\text { submit to the } \\
\text { impact of } \\
\text { new ideas for } \\
\text { reason of their } \\
\text { own interest } \\
\text { (consequence } \\
\text { logic) }\end{array}$ & $\begin{array}{l}\text { - ideas adopted } \\
\text { by actors who } \\
\text { are affected by } \\
\text { the institutional } \\
\text { environment; } \\
\text { changing their } \\
\text { preferences and, } \\
\text { consequently, } \\
\text { driving the } \\
\text { actors to create } \\
\text { new institutions, } \\
\text { - the actors } \\
\text { behave in } \\
\text { accordance with } \\
\text { new ideas which } \\
\text { have been insti- } \\
\text { tutionalized, as } \\
\text { they are guided } \\
\text { by a combina- } \\
\text { tion of the logic } \\
\text { of consequence } \\
\text { (within an } \\
\text { institution) } \\
\text { and the logic } \\
\text { of relevance, } \\
\text { causing a path } \\
\text { dependency } \\
\text { effect }\end{array}$ & $\begin{array}{l}\text { - ideas adopted } \\
\text { by the actors in } \\
\text { the socialization } \\
\text { and learning } \\
\text { process change } \\
\text { their cognitive } \\
\text { frameworks for } \\
\text { interpreting } \\
\text { the reality, } \\
\text { norms, cultural } \\
\text { conventions and, } \\
\text { consequently, } \\
\text { actions, } \\
\text { - actors behave } \\
\text { in accordance } \\
\text { with new ideas } \\
\text { which have been } \\
\text { institutionalized } \\
\text { as they are gu- } \\
\text { ided by the logic } \\
\text { of relevance }\end{array}$ & $\begin{array}{l}\text { - ideas are adop- } \\
\text { ted by the actors } \\
\text { who concur with } \\
\text { the supporting } \\
\text { arguments; } \\
\text { ideas change } \\
\text { the actors' } \\
\text { thinking about } \\
\text { institutions } \\
\text { and, consequ- } \\
\text { ently, drive the } \\
\text { change of the } \\
\text { institutions and } \\
\text { discourse (in } \\
\text { addition, actors } \\
\text { can pursue their } \\
\text { goals using ide- } \\
\text { as, and change } \\
\text { the policy in this } \\
\text { way), } \\
\text { - actors behave } \\
\text { in accordance } \\
\text { with new ideas } \\
\text { that have turned } \\
\text { into institutions } \\
\text { because they } \\
\text { are guided by } \\
\text { the logic of } \\
\text { relevance }\end{array}$ & $\begin{array}{l}\text { - ideas adopted } \\
\text { in the sociali- } \\
\text { zation, learning } \\
\text { and deliberation } \\
\text { process change } \\
\text { the world the } \\
\text { actors live in } \\
\text { and, consequ- } \\
\text { ently, change } \\
\text { their actions (in } \\
\text { addition, actors } \\
\text { can pursue their } \\
\text { goals using ide- } \\
\text { as, and change } \\
\text { the policy in this } \\
\text { way), } \\
\text { - actors behave } \\
\text { in accordance } \\
\text { with new ideas } \\
\text { because they } \\
\text { have accepted } \\
\text { them as their } \\
\text { own world (logic } \\
\text { of relevance) }\end{array}$ \\
\hline
\end{tabular}




\begin{tabular}{|c|c|c|c|c|c|}
\hline & $\begin{array}{l}\text { Rational choice } \\
\text { theory }\end{array}$ & $\begin{array}{l}\text { Historical } \\
\text { institutionalism }\end{array}$ & $\begin{array}{l}\text { Sociological } \\
\text { institutionalism }\end{array}$ & $\begin{array}{l}\text { Discoursive } \\
\text { institutionalism }\end{array}$ & Constructivism \\
\hline $\begin{array}{l}\text { The effects } \\
\text { of ideas }\end{array}$ & $\begin{array}{l}\text { - roadmaps } \\
\text { to provide } \\
\text { information } \\
\text { - focal points } \\
\text { to ensure col- } \\
\text { laboration and } \\
\text { stability } \\
\text { - weapons } \\
\text { making the } \\
\text { actors stronger } \\
\text { in their struggle } \\
\text { for institutional } \\
\text { change and for } \\
\text { power } \\
\text { - coalition } \\
\text { magnets }\end{array}$ & $\begin{array}{l}\text { - formation } \\
\text { of the actors' } \\
\text { perceptions of } \\
\text { the reality } \\
\text { - defining } \\
\text { interests } \\
\text { - filtering } \\
\text { choices } \\
\text { - defining } \\
\text { a problem and } \\
\text { its solution }\end{array}$ & \multicolumn{3}{|c|}{$\begin{array}{l}\text { - formation of the actors' interpretation of the reality } \\
\text { - interpretation of interests } \\
\text { - filtering choices } \\
\text { - interpreting and resolving a problem } \\
\text { - in discoursive institutionalism and constructivism: } \\
\text { if ideas are used strategically by actors, they can drive } \\
\text { a change of policies as they serve as weapons to give } \\
\text { the actors more strength in their political struggle, or } \\
\text { as coalition magnets }\end{array}$} \\
\hline
\end{tabular}

Source: author's own research.

\section{CONCLUSIONS}

Based on the completed analytical tasks, it has been found that ideas can constitute an explanatory factor as they have their own dynamics and therefore they deliver unique effects, influencing change or stability of policies. By revealing this dynamics in the course of analytic work, it was not only possible to raise awareness of the ways of influence exerted by ideas but also of their qualities and nature. The article demonstrates that the impact ideas have on the political process depends on the understanding of human behaviour in the field of politics. The article reviews the ideational dimension with reference to behaviours covered by the rational choice theory, by historical, sociological and discoursive institutionalism and constructivism. As a result, certain differences have been revealed between the above mentioned approaches in terms of understanding the impact of ideas. A summary of analysis results is presented in Table 1.

What the above-mentioned approaches have in common is a close link between ideas and political actors. Firstly, ideas are the product of cognitive processes taking place in the actors' minds. Secondly, the actors are the carriers of ideas. 
Thirdly, ideas affect the actors and the latter change the policies. Furthermore, it has been demonstrated through the analytic work that in addition to ideas, even if they are preferential as an explanatory factor, there are also other factors, such as institutions. In further research, it would be reasonable to reflect on the differences between the influence of ideas and of other factors, their mutual relationships and the interactions of ideas with other (e.g., earlier) ideas. Within the framework of study of ideas, the issue of the "force" of ideas should be considered as well, i.e., the extent of their impact and the conditions determining the "force".

\section{ReFERENCES:}

Béland, D. (2016). Ideas and Institutions in Social Policy Research. Social Policy \& Administration, 50(6), 734-750. DOI: 10.1111/spol.12258.

Béland, D., \& Cox, R.H. (2011). Introduction. In: D. Béland, \& R.H. Cox (eds.). Ideas and Politics in Social Science Research (pp. 3-20). Oxford-New York: Oxford University Press.

Béland, D., \& Cox, R.H. (2016). Ideas as Coalition Magnets: Coalition Building, Policy Entrepreneurs, and Power Relations. Journal of European Public Policy, 23(3), 428-445. DOI: 10.1080/13501763.2015.1115533.

Berman, S. (1998). The Social Democratic Moment: Ideas and Politics in the Making of Interwar Europe. Cambridge, MA: Harvard University Press.

Berman, S. (2013). Ideational Theorizing in the Social Sciences since "Policy Paradigms, Social Learning, and the State". Governance: An International Journal of Policy, Administration, and Institutions, 26(2), 217-237. DOI: 10.1111/gove.12008.

Blyth, M. (2001). The Transformation of the Swedish Model: Economic Ideas, Distributional Conflict, and Institutional Change. World Politics, 54(1), 1-26. DOI: 10.1353/ wp. 2001.0020

Blyth, M. (2002). Great Transformations: Economic Ideas and Institutional Change in the Twentieth Century. Cambridge: Cambridge University Press.

Blyth, M. (2006). Instytucje i idee. In: D. Marsh, \& G. Stoker (eds.). Teorie i metody w naukach politycznych (pp. 295-314). Kraków: Wydawnictwo Uniwersytetu Jagiellońskiego.

Campbell, J.L. (2002). Ideas, Politics, and Public Policy. Annual Review of Sociology, 28, 21-38. DOI: 10.1146/annurev.soc.28.110601.141111.

Cianciara, A.K. (2017). Europejska polityka sasiedztwa w perspektywie konstruktywizmu. Aktorzy, narracje, strategie. Warszawa: Instytut Studiów Politycznych Polskiej Akademii Nauk.

Garret, G., \& Weingast, B.R. (1993). Ideas, Interests and Institutions: Constructing the European Communities Internal Market. In: J. Goldstein, \& R. Keohane (eds.). Ideas and Foreign Policy: Beliefs, Institutions and Political Change (pp. 173-207). Ithaka, NY: Cornell University Press. 
Gofas, A., \& Hay, C. (2010). Varieties of Ideational Explanation. In: A. Gofas, \& C. Hay (eds.). The Role of Ideas in Political Analysis: A Portrait of Contemporary Debates (pp. 13-55). Abingdon, Oxon: Routledge.

Goldstein, J. (1993). Ideas, Interests and American Trade Policy. Ithaka, NY: Cornell University Press.

Hall, P. (1992). The Movement from Keynesianism to Monetarism: Institutional Analysis and British Economic Policy in the 1970s. In: S. Steinmo, K. Thelen, \& F. Longstreth (eds.). Structuring Politics: Historical Institutionalism in Comparative Analysis (pp. 90-111). Cambridge: Cambridge University Press.

Hay, C. (2006). Constructivist Institutionalism. In: R.A.W. Rhodes, S.A. Binder, \& B.A. Rockman (eds.). The Oxford Handbook of Political Institutions (pp. 56-74). Oxford: Oxford University Press.

McNamara, K.R. (1998). The Currency of Ideas: Monetary Politics in the European Union. Ithaka, NY: Cornell University Press.

Mehta, J. (2011). The Varied Roles of Ideas in Politics: From "Whether" to "How". In: D. Béland, \& R.H. Cox (eds.). Ideas and Politics in Social Science Research (pp. 23-46). Oxford-New York: Oxford University Press.

Parsons, C. (2010). Constructivism and Interpretive Theory. In: D. Marsh, \& G. Stoker (eds.). Theory and Methods in Political Science ( $3^{\text {rd }}$ ed.) (pp. 80-98). Basingstoke: Palgrave Macmillan.

Parsons, C. (2016). Ideas and Power: Four Intersections and How to Show Them. Journal of European Public Policy, 23(3), 446-463. DOI: 10.1080/13501763.2015.1115538.

Saurugger, S. (2013). Constructivism and Public Policy Approaches in the EU: From Ideas to Power Games. Journal of European Public Policy, 20(6), 888-906. DOI: 10.1080/13501763.2013.781826.

Saurugger, S. (2017). Sociological Institutionalism and European Integration. In: W.R. Thompson et al. (eds.). Oxford Research Encyclopedia of Politics. Oxford, USA: Oxford University Press. Retrieved from: https://oxfordre.com/politics/ view/10.1093/acrefore/9780190228637.001.0001/acrefore-9780190228637-e179 ? rskey=b5Aflv\&result=1. DOI: 10.1093/acrefore/9780190228637.013.17.

Schmidt, V.A. (2008). Discursive Institutionalism: The Explanatory Power of Ideas and Discourse. Annual Review of Political Science, 11(1), 303-326. DOI: 10.1146/ annurev.polisci.11.060606.135342.

Schmidt, V.A. (2010). Taking Ideas and Discourse Seriously: Explaining Change Through Discursive Institutionalism as the Fourth "New Institutionalism". European Political Science Review, 1(2), 1-25. DOI: 10.1017/S175577390999021X.

Tønder, L. (2010). Ideational Analysis, Political Change and Immanent Causality. In: A. Gofas, \& C. Hay (eds.). The Role of Ideas in Political Analysis. A Portrait of Contemporary Debates (pp. 55-77). Abingdon, Oxon: Routledge.

Wiener, A. (2006). Constructivism and Sociological Institutionalism. In: M. Cini, \& A.K. Bourne (eds.). Palgrave Advances in European Union Studies (pp. 35-55). Basingstoke: Palgrave Macmillan. 